\title{
ANALISIS RELIGIUSITAS TERHADAP MINAT MENABUNG DI BANK SYARIAH KOTA PEKANBARU
}

\author{
Eva Mardiana ${ }^{1}$, Husni Thamrin ${ }^{2} \&$ Putri Nuraini $^{3}$ \\ ${ }^{1 \& 2}$ Program Studi Ekonomi Syariah, Pascasarjana UIN SUSKA Riau \\ ${ }^{3}$ Fakultas Agama Islam, Universitas Islam Riau \\ Email:evamardianase@gmail.com, husni2017husni@gmail.com,putrinuraini@fis.uir.ac.id
}

\begin{abstract}
ABSTRAK
Religiusitas merupakan sikap hidup seseorang berdasarkan pada nilai-nilai yang diyakininya. Penelitian ini bertujuan untuk menganalisis pengaruh religiusitas terhadap minat menabung di bank Syariah pada guru pondok Modern Al-Kautsar Pekanbaru. Sampel yang digunakan dalam penelitian ini berjumlah 54 orang responden. Jenis penelitian ini adalah penelitian lapangan dengan pendekatan kuantitatif. Jenis data yang digunakan adalah data primer dengan Teknik analisis menggunakan regresi linier sederhana dengan pengolahan data menggunakan Software SPSS Versi 22. Pengujian hipotesis menggunakan analisis secara parsial (uji t). Hasil Penelitian ini menunjukkan bahwa religiusitas berpengaruh positif dan signifikan terhadap minat guru Pondok Modern al-Kautsar Pekanbaru untuk menabung di bank syariah. Hal ini dibuktikan dengan nilai $t_{\text {hitung }}$ variabel religiusitas (X) sebesar 7,756 dan nilai $t_{\text {tabel }}$ sebesar 1,671 maka terlihat bahwa: $t_{\text {hitung }}>t_{\text {tabel }}(7,756>1,671)$ dengan taraf signifikansi sebesar 0,000 lebih kecil dari $0,05(0,000<0,05)$. Selanjutnya, nilai koefisien determinasi ( $R$ Square) sebesar 0.536. Ini berarti pengaruh variabel independen (religiusitas) terhadap variabel dependen (minat menabung) sebesar 53,6\%, sedangkan sisanya sebesar 46,4\% dipengaruhi oleh variabel lain yang tidak diikutsertakan dalam penelitian ini.
\end{abstract}

Kata Kunci : Religiusitas, Minat Menabung, Bank Syariah.

\begin{abstract}
Religiosity is a person's attitude based on the values he believes in. This study aims to analyze the effect of religiosity on interest in saving in Islamic banks at Al-Kautsar Modern Islamic boarding school teachers Pekanbaru. The sample used in this study found 54 respondents. This type of research is field research with a quantitative approach. The type of data used is primary data with analysis technique using simple linear regression with data processing using SPSS Software Version 22. Hypothesis testing using partial analysis ( $t$ test). The results of this study indicate that religiosity has a positive and significant effect on the interest of Pondok Modern al-Kautsar Pekanbaru teachers to save in Islamic banks. This is evidenced by the $t$ count value of the religiosity variable $(X)$ of 7.756 and the value of $t$ table of 1.671, it can be seen that: $t$ count $>t$ table $(7.756>1.671)$ with a significance level of 0.000 less than $0.05(0.000<0.05)$. Furthermore, the coefficient of determination ( $R$ Square) is 0.536. This means that the influence of the independent variable (religiosity) on the dependent variable (interest in saving) is $53.6 \%$, while the remaining $46.4 \%$ is influenced by other variables not included in this study.
\end{abstract}

Keywords : Religiosity, Interest in Savings, Islamic Bank. 


\section{PENDAHULUAN}

Dalam

perjalanannya,

perkembangan pertumbuhan pendirian bank syariah mengalami kemajuan yang cukup signifikan. Fenomena pertumbuhan pendirian bank-bank syariah di Indonesia perlu kita apresiasi bersama. Berbagai upaya yang harus dilakukan bank syariah untuk meningkatan dan mengembangkan bank syariah itu sendiri adalah dengan meningkatkan strategi kualitas pelayanan, kemudian meningkatkan kerjasama dengan lembaga atau organisasi Islam khususnya Pondok pesantren untuk memberdayakan ekonomi syariah. Selain kualitas pelayanan, religiusitas juga berpengaruh terhadap minat dan keputusan menabung di perbankan syariah.

Minat merupakan sumber motivasi yang mendorong orang untuk melakukan apa yang mereka inginkan bila mereka bebas memilih (Hirmawan, 2015). Salah satu faktor yang mendasar didalam masyarakat terhadap minat menabung yakni faktor pendapatan masyarakat itu sendiri. Banyak masyarakat yang memiliki tingkat pendapatan yang berbeda sehingga minat menabung setiap individu juga berbeda. Selain itu juga terdapat faktor-faktor yang mempengaruhinya, antara lain kualitas pelayanan dan religiusitas.

Dalam meningkatkan kerjasama bank syariah dengan pondok pesantren tentu perlu adanya pengetahuan, pendekatan terhadap guru-guru yang mengajar dipondok pesantren. Perkembangan pendidikan yang berfokus pada ajaran agama Islam sangat berkembang, hal ini ditandai dengan adanya pondok pesantren yang merupakan salah satu unsur strategis dalam tatanan masyarakat. Apabila kalangan pesantren khususnya para kyai dan guru sudah mengenal dan memahami bank syariah, pengetahuan mereka tentang bank syariah diduga dapat memberikan manfaat kepada anak didiknya maupun kepada mayarakat disekitarnya.

Kota Pekanbaru adalah kota yang sangat pesat pertumbuhan pondok pesantren salah satunya adalah Pondok Modern alKautsar Pekanbaru. Guru yang mengajar di Pondok Modern Al-Kautsar lulusan S1, S2 dan S3 dari universitas didalam maupun di luar negeri berbekal ilmu pendidikan agama Islam dan ekonomi syariah. Maka dari itu, dengan bekal ilmu agama dan ekonomi syariah yang mereka miliki, akan mempengaruhi pandangan, pengetahuan, dan pemahaman mereka tentang bank syariah, terutama dengan minat menabung dan dapat menggunakan produk-produk perbankan syariah.

Dapat diasumsikan bahwa Pondok Modern Al-Kautsar Pekanbaru memiliki tingkat religiusitas yang tinggi karena lingkunganya mendukung seperti adanya guru dengan ilmu agama. Sehingga dengan demikian minat guru menabung di bank syariah juga semakin tinggi, karena masyarakat beragama Islam tentunya sudah mengetahui tentang prinsip-prinsip Islam salah satunya larangan riba.

\section{TINJAUAN PUSTAKA}

\section{Pengertian Religiusitas}

Religiusitas sebagai keberagamaan yang berarti meliputi berbagai macam sisi atau dimensi yang bukan hanya terjadi ketika seseorang melakukan perilaku ritual (beribadah), tapi juga ketika melakukan aktivitas lain yang didorong oleh kekuatan supranatural (Ancok \& Suroso, 2008). Menurut Pakkwaru (2018) religiusitas adalah sikap hidup seseorang berdasarkan pada nilai-nilai yang diyakininya. Religiusitas dalam konteks keislaman pun sudah tersirat dalam ajaran agama Islam dalam proses menjalankan ajaran agama secara kaffah atau menyeluruh. Jadi dapat didefinisikan bahwa religiusitas adalah kedalaman penghayatan keagamaan seseorang dan keyakinannya terhadap adanya tuhan yang diwujudkan dengan mematuhi perintah dan menjauhi larangan dengan keikhlasan hati dan dengan seluruh jiwa dan raga. 


\section{Dimensi Religiusitas}

Segi konteks religiusitas dalam Islam menurut Glock dan Stark dalam Ancok dan Suroso (2008) menyatakan bahwa terdapat 5 dimensi dalam religiusitas, yaitu:

1. Keyakinan (ideologis), tingkatan sejauh mana seseorang menerima hal-hal yang dogmatik dalam agamanya. Dimensi ini berisi pengharapan dimana orang yang religius berpegang teguh pada pandangan teologis tertentu dan mengakui kebenaran doktrin tersebut. Dengan sendirinya dimensi keyakinan ini menuntut dilakukannya praktek-praktek peribadatan yang sesuai dengan nilai-nilai Islam;

2. Praktik Agama (ritualistic), tingkatan sejauh mana seseorang mengerjakan kewajiban-kewajiban ritual dalam agamanya. Dimensi ini mencakup perilaku pemujaan, ketaatan, dan hal-hal yang dilakukan orang untuk menunjukkan komitmen terhadap agama yang dianut. Wujud dari dimensi ini adalah perilaku masyarakat agama tertentu yang dalam menjalankan ritual-ritual berkaitan dengan agama;

3. Pengalaman (eksperensial), perasaanperasaan atau pengalaman yang pernah dialami dan dirasakan. Dimensi ini mengacu indentifikasi akibat-akibat keyakinan keagamaan, praktik, pengalaman, dan pengetahuan seseorang dari hari kehari;

4. Pengetahuan Agama (intellectual), sejauh mana individu mengetahui, memahami tentang ajaran-ajaran agamanya, terutama yang ada dalam kitab suci dan sumber lainnya. Dalam Islam meliputi pengetahuan tentang isi Al-Quran, pokokpokok ajaran yang harus diimani dan dilaksanakan, hukum Islam dan pemahaman terhadap kaidah-kaidah keilmuan ekonomi Islam/Perbankan Syariah.

5. Konsekuensi, dimensi yang mengukur seberapa jauh perilaku seseorang dimotivasi oleh ajaran-ajaran agamanya dalam kehidupan sosial contohnya seperti apakah ia mengunjungi tetangganya yang sakit, menolong orang dalam kesulitan, mendermakan hartanya, dan sebagainya.

\section{Pengertian Minat}

Menurut Kamus Besar Bahasa Indonesia minat diartikan sebagai sebuah kecenderungan hati yang tinggi terhadap suatu gairah atau keinginan. Menurut Syah (2004), minat merupakan sikap positif dari seseorang terhadap sesuatu yang dilakukan dengan perasaan senang dan semangat sehingga dapat menerima tanpa membiarkannya. Jadi dapat dikatakan bahwa minat adalah kecenderungan atau kegiatan yang tinggi atau keinginan yang besar terhadap sesuatu sebagai interpretasi perasaan suka yang timbul atas aktivitasnya.

\section{Faktor-faktor yang Mempengaruhi Minat}

Faktor-faktor yang mempengaruhi timbulnya minat menurut Crow (1984) adalah yaitu:

1. Faktor kebutuhan dari dalam diri, Mengadah pada kebutuhan-kebutuhan yang muncul dari dalam individu, merupakan faktor yang berhubungan dengan dorongan fisik, motif, mempertahankan diri dari rasa lapar, rasa takut, rasa sakit, juga dorongan ingin tahu membangkitkan minat untuk mengadakan penelitian dan sebagainya;

2. Faktor motif sosial, mengarah pada penyesuaian diri dengan lingkungan agar diterima dan diakui oleh lingkungan atau aktivitas untuk memenuhi kebutuhan sosial, seperti bekerja, mendapatkan status, mendapatkan perhatian dan penghargaan;

3. Faktor emosional atau perasaan, minat yang erat hubungannya dengan perasaan atau emosi, keberhasilan dalam beraktivitas yang didorong oleh minat akan membawa rasa senang dan memperkuat minat yang sudah ada, sebaliknya kegagalan akan mengurangi minat individu tersebut. 


\section{METODE PENELITIAN}

Penelitian ini merupakan penelitian lapangan (field research). Jenis penelitian yang digunakan dalam penelitian ini adalah jenis penelitian deskriptif kuantitatif. Penelitian kuantitatif yaitu metode penelitian yang dipakai pada penelitian ini. Metode kuantitatif yaitu suatu metode analisisnya data-data numerical atau angka yang diolah dengan menggunakan metode statistika (Suranto, 2019). Penelitian ini dilaksanakan di Pondok Modern Al-Kautsar yang beralamat di Jl. Hangtuah KM 6,5 Kelurahan Bencah Lesung Kecamatan Tenayan Raya Pekanbaru Riau.

\section{Populasi dan Sampel}

Adapun populasi dalam penelitian ini adalah seluruh guru di lingkungan Pondok Modern Al-Kautsar Pekanbaru tahun 2021 yang berjumlah 54 orang. Sampel adalah bagian dari jumlah dan karakteristik yang dimiliki oleh populasi tersebut (Sugiyono, 2013). Dari jumlah populasi tersebut, maka seluruh populasi akan dijadikan sampel dengan menggunakan teknik total sampling.

\section{Uji Validitas}

Uji Validitas adalah kebenaran dan keabsahan instrumen penelitian yang digunakan, untuk mengetahui sah atau tidak valid nya suatu kuesioner. Item kuesioner/Instrumen dikatakan valid jika instrumen tersebut mengukur apa yang diukur pada uji validitas suatu variabel dikatakan valid jika memberi nilai $<0,05$ atau 5\% (Sanusi, 2017).

\section{Uji Reliabilitas}

Uji reliabilitas digunakan teknik Cronbach Alpha dimana instrumen dapat dikatakan handal atau reliabel bila memiliki koefisien kehandalan sebesar > 0,6 (Siregar, 2014). Uji reliabilitas dilakukan untuk menjamin instrumen yang digunakan merupakan instrumen handal dan dapat dipercaya.

\section{Uji Koefisien Determinasi $\left(\mathbf{R}^{2}\right)$}

Untuk mengatur seberapa besarnya kontribusi variabel $\mathrm{X}$ terhadap variabel $\mathrm{Y}$ digunakan uji koefisien determinasi berganda (Adjusted $R^{2}$ ) koefisien determinasi (Adjusted $R^{2}$ ) adalah besaran yang menunjukkan seberapa besar perubahan variabel terikat $(\mathrm{Y})$ yang dapat di pengaruhi oleh variabel bebas (X). (Riduwan, 2014). Uji koefisien determinasi $\left(\mathrm{R}^{2}\right)$ pada intinya mengukur seberapa jauh kemampuan model dalam menerangkan variasi variabel independen.

\section{Analisis Regresi Linear Sederhana}

Dalam menganalisa permasalahan dan pengujian hipotesis dalam penelitian ini maka peneliti menggunakan analisis regresi linear berganda (multiple regression). Rumus untuk regresi linear berganda dalam penelitian ini adalah sebagai berikut :

$$
\begin{aligned}
& \mathrm{Y}=\mathrm{a}+\mathrm{bX} \\
& \text { Keterangan: } \\
& \mathrm{Y}=\text { Minat Menabung } \\
& \mathrm{a}=\text { Konstanta } \\
& \mathrm{b}=\text { Koefisien Regresi } \\
& \mathrm{X}=\text { Religiusitas }
\end{aligned}
$$

\section{Uji Parsial (Uji t)}

Uji $\mathrm{t}$ dilakukan untuk mengetahui pengaruh masing-masing variabel bebas terhadap variabel terikat (Riduwan, 2014). Uji $\mathrm{T}$ digunakan untuk menguji secara parsial masing-masing variabel. Hasil uji t dapat dilihat pada tabel coefficients pada kolom sig (significance). Jika probabilitas nilai $\mathrm{t}$ atau signifikansi $<0,05$, maka dapat dikatakan bahwa terdapat pengaruh antara variabel bebas terhadap variabel terikat secara parsial. Namun, jika probabilitas nilai $\mathrm{t}$ atau signifikansi $>0,05$, maka dapat dikatakan bahwa tidak terdapat pengaruh yang signifikan antara masing-masing variabel bebas terhadap variabel terikat. 
HASIL DAN PEMBAHASAN

\section{Uji Validitas}

Pengukuran validitas dilakukan dengan menggunakan rumus Corrected Item-Total Correlation dengan taraf signifikan 5 $(\alpha=0,05)$ artinya suatu item dianggap valid jika berkorelasi signifikan terhadap skor total. Jika $r$ hitung $>\mathrm{r}$ tabel maka item-item pernyataan dinyatakan valid. Jika $r$ hitung $<r$ tabel maka item-item pernyataan dinyatakan tidak valid. Pengujian validitas selengkapnya dapat dilihat pada Tabel berikut ini:

Tabel 1. Hasil Uji Validitas

\begin{tabular}{ccccc}
\hline Variabel & Item Pernyataan & $\begin{array}{c}\text { Corrected Item- } \\
\text { total Correlation } \\
\text { (r Hitung) }\end{array}$ & R tabel $\mathbf{\alpha = 0 , 0 5}$ & Keterangan Hasil \\
\hline Religiusitas (X) & Item 1 & 0.621 & 0.279 & Valid \\
& Item 2 & 0.575 & 0.279 & Valid \\
& Item 3 & 0.446 & 0.279 & Valid \\
& Item 4 & 0.340 & 0.279 & Valid \\
& Item 5 & 0.284 & 0.279 & Valid \\
\hline \multirow{2}{*}{ Minat Menabung } & Item 6 & 0.364 & 0.279 & Valid \\
& Item 7 & 0.750 & 0.279 & Valid \\
& Item 8 & 0.615 & 0.279 & Valid \\
& Item 9 & 0.342 & 0.279 & Valid \\
\hline
\end{tabular}

Sumber : Data Olahan (2021)

Hasil Uji Validitas pada table 1 diatas dapat diketahui bahwa nilai $\mathrm{r}$ tabel sebesar 0,279 , nilai ini dibandingkan dengan nilai $r$ hitung. Nilai $r$ hitung dalam uji ini adalah pada kolom Item-Total Statistics (Corrected Item-Total Correlation). Dari tabel diatas menunjukkan bahwa butir pernyataan mempunyai nilai korelasi yang lebih besar dari $r$ tabel. Sehingga seluruh item-item variabel dinyatakan valid dan layak untuk dianalisis.

\section{Uji Reliabilitas}

Uji reliabilitas digunakan teknik Cronbach Alpha dimana instrumen dapat dikatakan handal atau reliabel bila memiliki koefisien kehandalan sebesar $>0,60$. Pengujian reliabilitas selengkapnya dapat dilihat pada Tabel berikut ini: 
Tabel 2. Hasil Uji Reliabilitas

\begin{tabular}{ccccc}
\hline Variabel & Item Pernyataan & $\begin{array}{c}\text { Corrected Alpha- } \\
\text { Item Deleted (r } \\
\text { Hitung) }\end{array}$ & Cronbach's Alpha & Keterangan Hasil \\
\hline Religiusitas (X) & Item 1 & 0.837 & 0.60 & Reliabel \\
& Item 2 & 0.841 & 0.60 & Reliabel \\
& Item 3 & 0.847 & 0.60 & Reliabel \\
& Item 4 & 0.859 & 0.60 & Reliabel \\
& Item 5 & 0.861 & 0.60 & Reliabel \\
\hline \multirow{2}{*}{ Minat Menabung } & Item 6 & 0.851 & 0.60 & Reliabel \\
& Item 7 & 0.831 & 0.60 & Reliabel \\
& Item 8 & 0.838 & 0.60 & Reliabel \\
& Item 9 & 0.874 & 0.60 & Reliabel \\
& Item 10 & 0.841 & 0.60 & Reliabel \\
\hline
\end{tabular}

Sumber : Data Olahan (2021)

Berdasarkan tabel diatas dapat demikian variabel religiusitas dan minat diketahui bahwa masing-masing variabel menabung dinyatakan reliabel.

memiliki cronbach's alpha $>0.60$. Dengan $\quad$ Uji Koefisien Determinasi $\left(\mathbf{R}^{\mathbf{2}}\right)$

Tabel 3. Hasil Uji Koefisien Derterminasi (R2)

\begin{tabular}{|c|c|c|c|c|}
\hline \multicolumn{5}{|c|}{ Model Summary } \\
\hline Model & $\mathrm{R}$ & R Square & Adjusted R Square & Std. Error of the Estimate \\
\hline 1 &, $732^{\mathrm{a}}$ &, 536 & ,527 & 1,393 \\
\hline
\end{tabular}

a. Predictors: (Constant), Religiusitas

Sumber : Data Olahan (2021)

Berdasarkan hasil pada tabel 3 diatas (minat menabung) sebesar 53,6\%, sedangkan menjelaskan bahwa besarnya nilai korelasi sisanya sebesar 46,4\% dipengaruhi oleh atau hubungan $(\mathrm{R})$ yaitu sebesar 0,732 . Dari variabel lain yang tidak diikutsertakan dalam tabel tersebut diperoleh nilai koefisien penelitian ini. determinasi ( $R$ Square) sebesar 0.536. Ini berarti pengaruh variabel independen

\section{Analisis Regresi Linear Sederhana} (religiusitas) terhadap variabel dependen

Tabel 4. Hasil Uji Regeresi Linear Sederhana

\begin{tabular}{|c|c|c|c|c|c|c|}
\hline \multicolumn{7}{|c|}{ Coefficients $^{a}$} \\
\hline \multirow{2}{*}{\multicolumn{2}{|c|}{ Model }} & \multicolumn{2}{|c|}{ Unstandardized Coefficients } & $\begin{array}{c}\text { Standardized } \\
\text { Coefficients }\end{array}$ & \multirow[b]{2}{*}{$\mathrm{t}$} & \multirow[b]{2}{*}{ Sig. } \\
\hline & & $\mathrm{B}$ & Std. Error & Beta & & \\
\hline \multirow[t]{2}{*}{1} & (Constant) & 8,034 & 1,744 & & 4,606 &, 000 \\
\hline & Religiusitas &, 629 & ,081 & ,732 & 7,756 & ,000 \\
\hline
\end{tabular}

a. Dependent Variable: Minat Menabung

Sumber : Data Olahan (2021) 
Berdasarkan tabel diatas, diketahui nilai Constanta (a) sebesar 8,034, sedangkan nilai religiusitas (b/koefisien regresi) sebesar 0,629 maka dapat disusun persamaan regresinya sebagai berikut:

$\mathrm{Y}=\mathrm{a}+\mathrm{bX}$

$\mathrm{Y}=8,034+0,629 \mathrm{X}$

Hasil interpretasi persamaan regresi diatas adalah:

a. Nilai konstanta (a) sebesar 8,034. Artinya adalah apabila religiusitas diasumsikan nol (0), maka minat menabung (Y) bernilai 8,034 .

b. Nilai koefisien regresi linier variabel religiusitas (X) sebesar 0,629. Artinya adalah bahwa setiap peningkatan religiusitas sebesar 1 satuan maka akan meningkatkan minat menabung (Y) sebesar 0,629. Koefisien regresi tersebut bernilai positif sehingga dapat dikatakan bahwa arah pengaruh variabel $\mathrm{X}$ terhadap Y adalah positif.

\section{Uji Parsial (Uji t)}

Dari table 4 tersebut juga dapat dilihat hasil uji t yang menyatakan bahwa nilai signifikansi sebesar $0,000<0,05$, sehingga dapat disimpulkan bahwa variabel religiusitas (X) berpengaruh terhadap variabel minat menabung (Y). Kemudian nilai $t_{\text {hitung }}$ variabel religiusitas $(X)$ sebesar 7,756 dan nilai $t_{\text {tabel }}$ sebesar 1,671 maka terlihat bahwa: $t_{\text {hitung }}>t_{\text {tabel }}$ atau 7,756 > 1,671. Hal ini menunjukkan bahwa $\mathrm{Ha}$ diterima dan Ho ditolak dengan tingkat signifikan sebesar 0,05 , dimana nilai (Sig) sebesar $0,000<0,05$ sehingga dapat dikatakan bahwa secara statistik berpengaruh positif dan signifikan antara religiusitas terhadap minat menabung.

\section{Pembahasan}

Penelitian ini bertujuan untuk mengetahui pengaruh religiusitas terhadap minat menabung di bank syariah pada guru Pondok Modern Al-Kautsar Pekanbaru. Berdasarkan hasil pengujian hipotesis dapat dijelaskan sebagai berikut: Hasil penelitian menunjukkan bahwa religiusitas berpengaruh positif dan signifikan terhadap minat menabung. Hasil uji statistik yang telah dilakukan menunjukkan nilai $t$ hitung variabel religiusitas sebesar 7,756 dengan taraf signifikansi sebesar $0,000<0,05$. Pengujian ini membuktikan bahwa religiusitas berpengaruh positif dan signifikan terdapat minat guru Pondok Modern al-Kautsar Pekanbaru untuk menabung di Perbankan Syariah. Hasil penelitian ini telah mendukung penelitian yang dilakukan oleh Purwanto (2016); Tripuspitorini (2019); Fauzi \& Murniawaty (2020). Hasil penelitian menunjukkan bahwa religiusitas dan tingkat pendapatan secara parsial berpengaruh positif dan signifikan terhadap minat masyarakat menabung di bank syariah. Namun, Berbeda dengan hasil penelitian yang dilakukan oleh Suprihati et al, (2021) yang menemukan bahwa religiusitas tidak berpengaruh signifikan terhadap minat nasabah menabung di koperasi syariah.

Pada lingkungan pesantren, sudah sepatutnya memiliki tingkat religiusitas yang tinggi. Seorang kiyai/guru yang lebih tua maka tingkat religiusitasnya semakin tinggi. Dengan tingginya ilmu agama yang dimiliki, maka tidak menutup kemungkinan meningkatkan minat menabung di bank Syariah yang mana produk-produk dan jasanya telah beroperasi menggunakan sistem Syariah serta berada dalam pengawasan Dewan Syariah Nasional. Hal ini juga akan berdampak kepada minat menabung pada perbankan Syariah.

Seseorang dapat dikatakan taat dalam agamanya apabila individu tersebut memiliki kontrol diri yang baik di dalam dirinya. Religi dapat mengontrol segala perilaku manusia, salah satunya adalah perilaku berhutang (dissaving). Perilaku ini sebagai salah satu cara masyarakat untuk memuaskan dan memenuhi kebutuhannya sangat memerlukan suatu kontrol agar tidak terjerumus ke dalam perilaku dissaving yang berlebihan. Menabung juga dapat mengotrol perilaku dissaving. 
Berdasarkan besarnya nilai korelasi atau hubungan (R) yaitu sebesar 0,732. Kemudian diperoleh nilai koefisien determinasi ( $R$ Square) sebesar 0.536. Ini berarti pengaruh variabel independen (religiusitas) terhadap variabel dependen (minat menabung) sebesar 53,6\%, sedangkan sisanya sebesar 46,4\% dipengaruhi oleh variabel lain yang tidak diikutsertakan dalam penelitian ini.

Religiusitas dapat mempengaruhi minat guru Pondok Modern al-Kautsar Pekanbaru untuk menabung di bank syariah. Semakin tinggi religiusitas, maka semakin tinggi minat guru Pondok Modern al-Kautsar Pekanbaru untuk menabung di bank syariah karena guru berkeyakinan bahwa menabung di bank syariah adalah salah satu cara ketaatan dan keyakinan mendalam setiap individu terhadap aturan-aturan Allah Subhanahu wa Ta'ala.

\section{KESIMPULAN}

Berdasarkan hasil analisis data dan pembahasan penelitian, maka dapat diambil kesimpulan bahwa religiusitas berpengaruh positif dan signifikan terhadap minat guru Pondok Modern al-Kautsar Pekanbaru untuk menabung di bank syariah. Sehingga semakin tinggi religiusitas maka semakin tinggi minat guru Pondok Modern al-Kautsar Pekanbaru untuk menabung di bank syariah. Penelitian ini menyarakankan bagi Perbankan Syariah, perlu mengupayakan adanya kerjasama antara institusi terkait dengan pihak pondok pesantren. Kemudian mengoptimalkan upaya sosialisasi yang intensif baik melalui personal (kiyai/guru), media masa elektronik dan media cetak lainnya. Diharapkan dapat memeberikan gambaran yang jelas tentang sistem dan produk perbankan Syariah dilingkungan pondok pesantren.

\section{DAFTAR PUSTAKA}

Ancok, D., \& Suroso, F. N. 2008. Pisikologi Islam: Solusi atas Problem-Problem Psikologi. Pustaka Belajar. Yogyakarta.
Crow. 1984. Psikologi Pendidikan. Terjemahan Rochman Abror. Nur Cahaya. Yogyakarta.

Fauzi, A., \& Murniawaty, I. 2020. Pengaruh Religiusitas dan Literasi Keuangan Syariah Mahasiswa terhadap Minat Menjadi Nasabah di Bank Syariah. Economic Education Analysis Journal, 9(2), p. 473-486.

Hirmawan, Muh Risky Adi. 2015. FaktorFaktor yang Mempengaruhi Minat Nasabah Bertransaksi di Bank Syariah (Studi Kasus di Bank Jateng Syariah Cabang Surakarta). Skripsi. Program Studi Akuntansi Fakultas Ekonomi dan Bisnis, Surakarta.

Pakkawaru, Irham. 2018. Pengaruh Tingkat Religiusitas, Kualitas Layanan Terhadap Keputusan Menabung dan Informasi Sebagai Variabel Moderating. Jurnal Bilancia, 12(2), p. 365-387.

Purwanto, A. 2016. Pengaruh Pengetahuan, Religiusitas, dan Tingkat Pendapatan Terhadap Minat Masyarakat Menabung di Bank Syariah. Skripsi, IAIN Salatiga.

Riduwan. 2010. Metode dan Teknik Menyusun Tesis. Alfabeta. Bandung.

Sanusi, Anwar. 2017. Metodologi Penelitian Bisnis. Salemba Empat. Jakarta.

Siregar. 2014. Metode Penelitian Kuantitatif. Kencana. Jakarta.

Sugiyono. 2013. Metode Penelitian Kombinasi, Mixed Methods. Alfabeta. Bandung.

Suprihati. Sumadi., \& Tho'in, Muhammad. 2021. Pengaruh Religiusitas, Budaya, Pengetahuan terhadap Minat Masyarakat Menabung di Koperasi Syariah. Jurnal Ilmiah Ekonomi Islam (JIEI), 7(10), p. 443-450.

Suranto. 2019. Metodologi Penelitian dalam Pendidikan dengan Program SPSS. Loka Aksara. Tangerang. 
2021, Jurnal Tabarru' : Islamic Banking and Finance 4 (2) : 512 - 520

Syah, Muhibbin. 2004. Psikologi Pendidikan. Remaja Rosda Karya. Bandung.

Tripuspitorini, Fifi Afiyanti. 2019. Pengaruh Religiusitas terhadap Minat Mahasiswa Politeknik Negeri Bandung Untuk Menabung di Bank Syariah. Jurnal Masharif al-Syariah: Jurnal Ekonomi dan Perbankan Syariah, 4(2), p. 54-69. 